\title{
Development and Reproduction of Three Predatory Mites (Acari: Laelapidae and Rhodacaridae) on Eggs of Ephestia kuehniella (Lepidoptera: Pyralidae)
}

\author{
M. F. $\operatorname{HASSAN}^{1}$, F. M. MOMEN ${ }^{2}$, A. K. NASR, ${ }^{2}$ A. H. MABROUK ${ }^{1}$, \\ and M. M. RAMADAN ${ }^{2}$ \\ ${ }^{1}$ Department of Zoology and Agriculture Nematology, Faculty of Agriculture, Cairo University, Cairo, Egypt \\ ${ }^{2}$ Pests and Plant Protection Department, National Reseach Centre (NRC), \\ 31 El-Bouhoth Street, 12311 Dokki, Cairo, Egypt
}

(Received: 24 October 2016; accepted: 25 November 2016)

\begin{abstract}
The laelapid mites Cosmolaelaps keni and Laelaspis astronomicus beside the rhodacarid mite Protogamasellopsis denticus are biological control agents and being native predators in Egypt. In order to raise active population of above species, the biology and demographic parameters, of the three tested species were observed under laboratory conditions with eggs of Ephestia kuhniella. All predatory species were developed and reproduced with E. kuhniella eggs. The mean developmental and oviposistion periods of L. astronomicus females were the longest from the other tested species. The mean longevity of $C$. keni was longer than that of P. denticus. Cosmolaelaps keni consumed more E. kuhniella eggs during the oviposition and adult longevity periods than other species did. Protogamasellopsis denticus fed on E. kuhniella food gave the most rate of oviposition as shown by the maximum fertility, net reproductive rate and gross reproductive rate. Laelaspis astronomicus preying on E. kuhniella eggs gave the longest generation time, lowest rate of fecundity and all life table parameters compared to other tested species; therefore E. kuhniella eggs was appropriate for the oviposition of P. denticus and C. keni rather than L. astronomicus.

This study is the first to report that E. kuhniella eggs were an acceptable factitious food for P. denticus, L. astronomicus and C. keni.
\end{abstract}

Keywords: Acari, Laelapidae, Ascidae, factitious food, Pyralidae, biological control.

Laelapidae family is predators of small pests living in soil (Beaulieu, 2009). Some species of laelapid mites proved that, they may be play an important role in biological control of pest mites, insects or nematode which spends all or part of their lives in the soil (Walter and Proctor, 1999). A Cosmolaelaps vacua (Michael) was found to complete its development when feeding on eggs of house fly (Abou-Awad et al., 1989). Cosmolaelaps simiplex (Berlese) and Cosmolaelaps qassimensis (Fouly and Abdel-Baky) are effective biocontrol agents against the nematodes Tylenchulus semipenetrans ( $\mathrm{Cobb}$ ), Meloidogyne javanica Treub and Meloidogyne incognita Chitwood (Meloidogynidae) and the acarid mites, Caloglyphus rodriguez, Samsinak and Tyrophagus puterscentiae (Schrank) (Al-Re-

* Corresponding author; e-mail: fatmomen@yahoo.com 
hiayani and Fouly, 2005; Fouly and Abdel-Baky, 2015). Laelaspis astronomicus (Koch) is also polyphagous predator and therefore females able to feed and sustain oviposition on two species of nematodes and acarid mites (Nawar, 2011). Recently, Moreira et al. (2015) presented the importance of Cosmolaelaps jaboticabalensis Moreira, Klompen and Moraes in controlling thrips Franklinella occidentalis (Pergande) and Protorhabditis $\mathrm{sp}$. Another group of predatory mites is the Rhodacaridae family, which forms frequently encountered in deeper soil layer, even into lying ground water habitat (Krantz, 1978). Lee (1970) indicated that no published data on the potential of the rhodacarids, in a strict taxonomic sense as biological control agents. Rhodacarids was observed by Sardar and Murphy (1987) to prey on small collembolans, immature oribatid mites and nematodes. Lately, two Protogamasellopsis sp. was cited in the literature as being predatory mites ex: Protogamasellopsis posnaniensis Wisniewski and Hirschmann was able to consume and reproduce on various prey with highly preference to T. puterscentiae, F. occidentalis and Protorhabditis sp. (Castilho et al., 2009); Protogamasellopsis zaheri Abo-Shnaf, Castilho and Moraes was able to feed and sustain oviposition on various acarid species, with the highest oviposition on Aleuroglyphus ovatus (Tropeau) and Cosmoglyphus oudemansi (Zachvatkin) (Barbosa and de Moraes, 2016).

One of the main inhibitions for the applied use of augmentative biological control in the managements of mite/insect pests is the high price of commercially produced natural enemy (De-Clercq et al., 1998). Providing solely formed unnatural food may help the mass rearing of these greedy predatory mites/insects to be more economical.

Tyrophagus puterscentiae was used as a factitious food to produce most of soil mites in large scale (Steiner et al., 1999; Freire and Moraes, 2007).

Factitious food rise the economic value of marketable production systems as predators can be reared at high bulks in a rearing component (Zhang, 2003).

Eggs of Ephestia kuehniella Zeller (Lepidoptera: Pyralidae) are of high nutritional value (richer in protein and amino acid) and have shown to be appropriate factitious food for the mass-rearing and field releases of insect predators, ex: the mirid bugs, Nesidiocoris tenuis (Reuter), Macrolophus pygmaeus Rambur (Hemiptera: Miridae) (Molla et al., 2014) and the predatory stinkbug, Andrallus spinidens (F) (Heteroptera: Pentatomidae) (Mohaghegh and Amir-Maafi, 2007).

Some of phytoseiid mites (Mesostigmata: Phytoseiidae) were succeeded to complete the development and oviposited on factitious prey (E. kuehniella eggs) (Vantornhout et al., 2004; Momen and El-Laithy, 2007; Nguyen et al., 2014; Vangansbeke et al., 2014).

The association between laelapid and rhodacarid mites and their future factitious prey has been little reported in the literature. For example Gaeolaelaps aculeifer Canestrini and Stratiolaelaps scimitus (Womersley) succeeded to oviposit on various factitious prey including eggs of E. kuehniella (Navarro-Campos et al., 2016); C. jaboticabalensis developed and reproduced on $T$. putrescentiae as prospective factitious food (Moreira et al., 2015).

Knowledge of the biology of Cosmolaelaps keni Hafez, El-Badry and Nasr, L. astronomicus and Protogamasellopsis denticus (Nasr) is limited. In their research, Saber et al. (2007) misidentified the species P. denticus and referred it to the genus Protogamasellus Karg being in the family Ascidae (Protogamasellus denticus Nasr), presumably the 
above authors did not check some character's cited by Evans and Purvis (1987), accordingly some species moved from the family Ascidae to the close one Rhodacaridae. Protogamasllopsis denticus is among other species moved to the family Rhodacaridae based on the taxonomical criteria cited by Evans and Purvis (1987).

Here we assume that C. keni, L. astronomicus and P. denticus feed, oviposited and increases in great numbers on E. kuehniella eggs, then, selection of the best performed one which can be reared easily on that food for augmentative biological control.

So, the objective of this paper was to evaluate the relative nutritional quality of E. kuehniella eggs as factitious food source for those predators.

The generic concepts of the family Laelapidae follow those of Evans and Till (1979).

\section{Materials and Methods}

\section{Host and mesostigmatic predatory mites'culture}

Adult females of $C$. keni and L. astronomicus were obtained from soil associated with roots of tomato plants (Lycopersicom esculentum) L. at Tanta Governorate in February 2015. Individuals of $P$. denticus were collected in deep soil (20 cm deep) samples under banana trees (Musa cavendishii) L. (Family: Musaceae) at Faywam region, Egypt in 2014. Modified Tullgran funnels with 25 watt bulbs were used to extract living mites in moistened plaster-lined glass Jars. Soil samples was placed in each funnel and mites removed from collection Jars using a very fine paintbrush after 2-4 days. Different species of mites were cultured separately in plastic cells $(2.5 \mathrm{~cm}$ in diameter and $2 \mathrm{~cm}$ in depth) containing a floor of plaster of Paris and charcoal (mixed in a 9: 1 ratio) were used. For biological experiments, small plastic cells $(1.0 \mathrm{~cm}$ in diameter and $0.8 \mathrm{~cm}$ in depth) were used. A large heavy glass cover was used for each cell to prevent mites from escaping. Activated plaster floor kept humid by daily addition of water.

Insect eggs were added daily to each predator as food. All predatory mites was reared on E. kuehniella eggs for 3 months before experiments in the laboratory of (NRC), Egypt. Feeding experiments were conducted in the laboratory at $28 \pm 1{ }^{\circ} \mathrm{C}$ and $70-75 \%$ relative humidity (RH). The newly deposited eggs by female's C. keni, L. astronomicus and $P$. denticus were singly removed from cultures in large cells to the small one for different biological tests.

\section{Test diet}

Fresh eggs of E. kuehniella were obtained daily from the Insect Department of (NRC), Egypt. 
Effect of E. kuehniella eggs on the development, consumption, reproduction and demographic parameters

A total of 30 eggs of C. keni, 26 of L. astronomicus and 20 of P. denticus could be considered for the tested food, was transferred singly to the small cells. Each larva of predatory species was provided with additional of E. kuehniella eggs (more than that consumed daily). The number of consumed eggs was calculated daily. Fresh eggs were replaced daily.

The developmental periods of different stages of each predator were recorded every $12 \mathrm{~h}$. Newly emerged females of each species were allowed to copulate with males on cells if necessary. The experimental cells were examined every $24 \mathrm{~h}$ to determine the duration of various physiological periods, daily consumption and oviposition rates as well as sex ratio of the progeny being calculated, too. Consumed eggs were recognized based on the occurrence of a hole or slit and a shriveled or hollow appearance. Predatory mites periodically mounted in Hoyer's medium to confirm colony identy and purity. All of the experiments were conducted under laboratory conditions of $28 \pm 1^{\circ} \mathrm{C}$ and $70-75 \%(\mathrm{RH})$.

\section{Statistical analysis}

Data presented in this paper were analyzed by one-way ANOVA and means between tested species were compared by Tukey HSD $(\mathrm{P}=0.05$ level).

\section{Life table}

The demographic parameters were calculated using Huang and Chi (2013) and their definition were those proposed by Birch (1948).

\section{Results and Discussion}

Effect of E. kuehniella eggs on development, survival and consumption rate

Larvae of all tested predatory mites are non-feeding type. Similarly, larvae of other laelapid mites ex: C. vacua, C. simplex, S. scimitus and C. jaboticabalensis did not feed (Abou-Awad et al., 1989; Al-Rehiayani and Fouly, 2005; Cabrera et al., 2005; Moreira et al., 2015).

Fresh E. kuehniella eggs were readily accepted by immature stages of all tested predators as factitious food. Protonymphs of C. keni, L. astronomicus and P. denticus developed and completed their life cycle on E. kuehniella eggs (Table 1). Because of the egg and larval stages of tested predatory mites are non-feeding instars, similar durations of both stages were expected in presence of insect diet. The mean development time of L. astronomicus from larva to adult female was significantly longer $\left(\mathrm{F}=10.243 \mathrm{df}_{2,50}\right.$ $p=0.000$ ) than that of $C$. keni and P. denticus. Comparing our results with other laelapid mites, indicated that: the life cycle period of $C$. qassimensis, $C$. simplex and $C$. jaboti- 
cabalensis fed various nematodes ex: $M$. incognita, $M$. javanica and T. semipenetrans as well as the acarid mite Caloglyphus rodriguez Samsinak and F. occidentalis was twice longer than predatory laelapid mites in the present study (Al-Rehiayani and Fouly, 2005; Fouly and Abdel-Baky, 2015; Moreira et al., 2015). Results of duration of P. denticus life cycle were comparable to what has been mentioned by Castilho et al. (2009) for P. posnaniensis fed $T$. putrescentiae. The immature stages of $P$. denticus consumed a significantly lower number of E. kuehniella eggs $\left(\mathrm{F}=23.272, \mathrm{df}_{2,50}, p=0.000\right)$ than both other nymphs of predatory mites did (Table 2). Immatures of $C$. vacua was able to consume an average of 33.0 nymphs of Rhizoglyphus echinopus (Fum. and Rob.) and 13.0 eggs of Musca domestica L. to reach the female stage (Abou-Awad et al., 1989).

\section{Effects of E. kuehniella eggs on longevity, consumption and fecundity}

In all predatory mites, male was found in each culture. The mean pre-oviposition period was likewise in $C$. keni and L. astronomicus. The shortest mean oviposition period (25.05 and 29.85 days) was recorded on P. denticus and C. keni, whereas L. astronomicus resulted in the longest mean oviposition duration $(36.13$ days $)\left(\mathrm{F}=11.258, \mathrm{df}_{2,50}\right.$, $p=0.000$ ) (Table 1). Insignificant difference was detected on the adult longevity of both predatory mites L. astronomicus and P. denticus $\left(\mathrm{F}=4.109, \mathrm{df}_{2,50}, p=0.022\right)$ (Table 1). A similar trend was observed for female life span of above both predators. Ahmed (1992) recorded that when the laelapid mite, Hypoaspis zachvtkinae Sherif and Afifi fed larvae

\section{Table 1}

Mean developmental periods (mean \pm SE in days) of Protogamasellopsis denticus, Cosmolaelaps keni and Laelaspis astronomicus females fed Ephestia kuhniella eggs at $28 \pm 1{ }^{\circ} \mathrm{C}$ and $70 \pm 5 \% \mathrm{R}$. H.

\begin{tabular}{lccccc}
\hline \multirow{2}{*}{$\begin{array}{c}\text { Developmental } \\
\text { stages }\end{array}$} & $\begin{array}{c}\text { P. denticus } \\
\left(18^{\mathrm{z}}\right)\end{array}$ & $\begin{array}{c}\text { C. keni } \\
\left(20^{\mathrm{z}}\right)\end{array}$ & $\begin{array}{c}\text { L. astronomicus } \\
\left(15^{\mathrm{z}}\right)\end{array}$ & $\begin{array}{c}\text { Calculated (F) } \\
\text { value }\end{array}$ & Probability \\
\cline { 2 - 5 } Egg & $1.88 \pm 0.11 \mathrm{a}^{\mathrm{y}}$ & $1.85 \pm 0.13 \mathrm{a}$ & $1.87 \pm 0.09 \mathrm{a}$ & $0.030^{\mathrm{ns}}$ & 0.971 \\
Larva & $1.00 \pm 0.00 \mathrm{a}$ & $1.00 \pm 0.00 \mathrm{a}$ & $1.13 \pm 0.09 \mathrm{a}$ & $2.758^{\text {ns }}$ & 0.073 \\
Protonymph & $2.11 \pm 0.14 \mathrm{a}$ & $1.90 \pm 0.10 \mathrm{a}$ & $2.13 \pm 0.09 \mathrm{a}$ & $1.356^{\mathrm{ns}}$ & 0.267 \\
Deutonymph & $1.94 \pm 0.09 \mathrm{a}$ & $2.00 \pm 0.07 \mathrm{a}$ & $2.73 \pm 0.18 \mathrm{~b}$ & $13.124^{*}$ & 0.000 \\
Life cycle & $6.94 \pm 0.15 \mathrm{a}$ & $6.75 \pm 0.17 \mathrm{a}$ & $7.87 \pm 0.21 \mathrm{~b}$ & $10.243^{*}$ & 0.000 \\
Pre-oviposition & $1.22 \pm 0.10 \mathrm{a}$ & $1.75 \pm 0.12 \mathrm{~b}$ & $2.06 \pm 0.22 \mathrm{~b}$ & $7.695^{*}$ & 0.001 \\
Oviposition & $25.05 \pm 1.61 \mathrm{a}$ & $29.85 \pm 1.42 \mathrm{a}$ & $36.13 \pm 1.78 \mathrm{~b}$ & $11.258^{*}$ & 0.000 \\
Post-oviposition & $11.38 \pm 2.06 \mathrm{~b}$ & $13.45 \pm 1.32 \mathrm{~b}$ & $3.27 \pm 0.24 \mathrm{a}$ & $11.982^{*}$ & 0.000 \\
Adult longevity & $37.66 \pm 2.41 \mathrm{a}$ & $45.05 \pm 1.24 \mathrm{~b}$ & $41.47 \pm 1.93 \mathrm{ab}$ & $4.109^{*}$ & 0.022 \\
Life-span & $44.61 \pm 2.41 \mathrm{a}$ & $51.80 \pm 1.17 \mathrm{~b}$ & $49.33 \pm 2.10 \mathrm{ab}$ & $3.855^{*}$ & 0.028 \\
\hline
\end{tabular}

\footnotetext{
${ }^{\mathrm{y}}$ Means within a row followed by the same letter are not significantly different (Tukey HSD, a $=0.05$ )

${ }^{\mathrm{Z}}$ Numbers between parentheses represent the number of replicates; * Significant at $P=0.05 ; \mathrm{df}=2,50$; ns = non-significant
} 


\section{Table 2}

Mean total and daily number of Ephestia kuhniella eggs consumed during the developmental periods and adult longevity of Protogamasellopsis denticus, Cosmolaelaps keni and Laelaspis astronomicus females at $28 \pm 1{ }^{\circ} \mathrm{C}$ and $70 \pm 5 \% \mathrm{R} . \mathrm{H}$.

\begin{tabular}{|c|c|c|c|c|c|c|c|c|}
\hline \multirow{3}{*}{$\begin{array}{l}\text { Female } \\
\text { stages } \\
\text { Larva }\end{array}$} & \multicolumn{2}{|c|}{$\begin{array}{l}\text { Protogamasellopsis denticus } \\
\qquad\left(18^{\mathrm{z}}\right)\end{array}$} & \multicolumn{2}{|c|}{ Cosmolaelaps keni $\left(20^{z}\right)$} & \multicolumn{2}{|c|}{ Laelaps astronomicus $\left(15^{2}\right)$} & \multicolumn{2}{|c|}{ Calculated (F) } \\
\hline & Total & Daily & Total & Daily & Total & Daily & Total & Daily \\
\hline & \multicolumn{6}{|c|}{ Non-feeding instar } & & \\
\hline $\begin{array}{l}\text { Proto- } \\
\text { nymph }\end{array}$ & $7.94 \pm 2.06 \mathrm{~A}^{\mathrm{y}}$ & $3.55 \pm 0.65^{\mathrm{a}}$ & $7.55 \pm 1.08 \mathrm{~A}$ & $4.10 \pm 0.56 \mathrm{a}$ & $9.73 \pm 1.03 \mathrm{~A}$ & $4.62 \pm 0.52 \mathrm{a}$ & $0.561^{\mathrm{ns}}$ & $0.784 \mathrm{~ns}$ \\
\hline $\begin{array}{l}\text { Deu- } \\
\text { tonymph }\end{array}$ & $9.83 \pm 0.96 \mathrm{~A}$ & $4.97 \pm 0.44 a$ & $16.25 \pm 1.20 \mathrm{~A}$ & $8.24 \pm 0.60 b$ & $25.66 \pm 2.55 \mathrm{~B}$ & $10.21 \pm 1.25 b$ & $23.272 *$ & $11.058^{*}$ \\
\hline Life cycle & $17.77 \pm 2.75 \mathrm{~A}$ & $4.24 \pm 0.53 \mathrm{a}$ & $23.80 \pm 1.84 \mathrm{~A}$ & $6.19 \pm 0.50 b$ & $35.40 \pm 1.77 \mathrm{~B}$ & $7.57 \pm 0.56 b$ & $15.150 *$ & $9.430 *$ \\
\hline $\begin{array}{l}\text { Pre- } \\
\text { oviposition }\end{array}$ & $5.88 \pm 0.53 \mathrm{~A}$ & $5.05 \pm 0.45 a$ & $14.80 \pm 2.17 \mathrm{~A}$ & $8.56 \pm 1.03 b$ & $29.40 \pm 5.20 \mathrm{~B}$ & $13.30 \pm 1.39 \mathrm{c}$ & $15.049 *$ & $15.950 *$ \\
\hline $\begin{array}{l}\text { Oviposi- } \\
\text { tion }\end{array}$ & $361.72 \pm 22.60 \mathrm{~A}$ & $14.54 \pm 0.49 a$ & $576.90 \pm 31.75 \mathrm{~B}$ & $19.58 \pm 1.10 \mathrm{~b}$ & $463.00 \pm 19.13 \mathrm{~A}$ & $12.95 \pm 0.30 \mathrm{a}$ & $17.859^{*}$ & $19.459 *$ \\
\hline $\begin{array}{l}\text { Post- } \\
\text { oviposition }\end{array}$ & $263.28 \pm 49.19 \mathrm{~B}$ & $22.84 \pm 1.12 b$ & $367.35 \pm 39.70 \mathrm{~B}$ & $28.73 \pm 1.74 c$ & $25.33 \pm 1.89 \mathrm{~A}$ & $7.89 \pm 0.39 a$ & $19.104 *$ & $60.888 *$ \\
\hline $\begin{array}{l}\text { Adult } \\
\text { longevity }\end{array}$ & $630.89 \pm 54.49 \mathrm{~A}$ & $16.42 \pm 0.64 b$ & $959.05 \pm 22.94 \mathrm{~B}$ & $21.37 \pm 0.32 c$ & $517.73 \pm 21.29 \mathrm{~A}$ & $12.60 \pm 0.30 \mathrm{a}$ & $39.437 *$ & $90.970 *$ \\
\hline Life-span & $648.67 \pm 54.80 \mathrm{~A}$ & $15.21 \pm 0.61 b$ & $982.85 \pm 23.03 B$ & $20.13 \pm 0.26 \mathrm{c}$ & $553.13 \pm 20.94 \mathrm{~A}$ & $12.06 \pm 0.31 \mathrm{a}$ & $38.138 *$ & $89.85^{*}$ \\
\hline
\end{tabular}

Means within a row followed by the same upper-case letter (total consumption rate) and lower-case letter (daily consumption rate) are not significantly different (Tukey HSD, $\mathrm{a}=0.05$ );

${ }^{\mathrm{Z}}$ Numbers between parentheses represent the number of replicates;

* Significant at $P=0.05 ; \mathrm{df}=2,50$;

$\mathrm{ns}=$ non-significant 
of $M$. domestica and Drosophila melanogaster (Meigen), the duration of the adult longevity were (22.7 and 20.3 days), while Moreira et al. (2015) found a longer period of adult longevity for C. jaboticabalensis fed F. occidentalis (57.7 days). Castilho et al. (2009) indicated that the adult longevity for the rhodacarid mite $P$. posnaniensis was 68.0 days with a longer post-oviposition being 38.8 days on $T$. putrescentiae which approximately less than 2 and 3 times longer of the adult longevity and corresponding stage in the rhodacarid species $P$. denticus fed E. kuehniella eggs.

The maximum consumption rate was recorded for the adult females during the oviposition periods as $P$. denticus was consumed a total average of 361.72 E. kuehniella eggs, while $C$. keni and L. astronomicus consumed a total average of 576.90 and 463.00 eggs, respectively (Table 2). In other species of the family Laelapidae and Rhodacaridae, $C$. jaboticabalensis was able to attack 54.1 pre-pupae/pupae of $F$. occidentalis per adult predator; while P. pasnaniensis being able to consume an average of 12.8, 23.5 individuals of R. echinopus and $T$. puterscentiae as factitious food, with maximum laid eggs on the latter prey (Castilho et al., 2009; Moreira et al., 2015). Females of G. aculeifer consumed an average of 12.3 thrips larvae during the 3 days period, while $S$. scimitus attacked 8.3 individuals (Navarro-Campos et al., 2016). The present study has revealed that the mean predation rate of E. kuehniella eggs is considerably very high in $C$. keni, and this result support the probability that $C$. keni is able to feed positively and reach a very high population under certain condition. On E. kuehniella eggs, the oviposition period of C. keni was as long, its fertility was about one and half and its net reproductive rate about twice more than determined by Moreira et al. (2015) for $C$. jaboticabalensis fed F. occidentalis and Protorhahditis sp.

The highest mean total number of eggs deposited per female was on P. denticus, while the lowest being on L. astronomicus $\left(\mathrm{F}=6346.608, \mathrm{df}_{2,50}, p=0.000\right)$ (Table 3). Re-

Table 3

Mean total fecundity and life table parameters of Protogamasellopsis denticus, Cosmolaelaps keni and Laelaps astronomicus females, fed Ephestia kuehniella eggs at $28 \pm 1{ }^{\circ} \mathrm{C}$ and $70 \pm 5 \% \mathrm{R}$. H.

\begin{tabular}{|c|c|c|c|c|}
\hline \multirow[b]{2}{*}{ Life table parameters } & \multicolumn{3}{|c|}{ Predatory mites } & \multirow{2}{*}{$\begin{array}{c}\text { Calculated }(\mathrm{F}) \\
\text { value }\end{array}$} \\
\hline & $\begin{array}{l}\text { Protogamasellopsis } \\
\text { denticus }\left(18^{z}\right)\end{array}$ & $\begin{array}{c}\text { Cosmolaelaps keni } \\
\left(20^{z}\right)\end{array}$ & $\begin{array}{c}\text { Laelaspis } \\
\text { astronomicus }\left(15^{z}\right)\end{array}$ & \\
\hline $\begin{array}{l}\text { Mean total fecundity } \\
\text { (no. eggs/female) }\end{array}$ & $116.86 \pm 0.158 \mathrm{a}^{\mathrm{y}}$ & $99.94 \pm 0.320 b$ & $78.64 \pm 0.214 \mathrm{c}$ & $6346.608 * *$ \\
\hline Intrinsic rate of increase $\left(\mathrm{r}_{\mathrm{m}}\right)$ & $0.33 \pm 0.001 b$ & $0.35 \pm 0.001 \mathrm{a}$ & $0.26 \pm 0.001 \mathrm{c}$ & $2229.808 * *$ \\
\hline Net reproductive rate $\left(\mathrm{R}_{\mathrm{O}}\right)$ & $99.63 \pm 0.922 \mathrm{a}$ & $86.73 \pm 0.728 b$ & $65.61 \pm 0.693 c$ & $475.741 * *$ \\
\hline Mean generation time $(\mathrm{T})$ & $13.86 \pm 0.24 b$ & $12.82 \pm 0.29 \mathrm{c}$ & $16.41 \pm 0.42 \mathrm{a}$ & $3280.637 * *$ \\
\hline Finite rate of increase $(\lambda)$ & $1.39 \pm 0.002 b$ & $1.42 \pm 0.002 \mathrm{a}$ & $1.29 \pm 0.001 \mathrm{c}$ & $2164.124 * *$ \\
\hline Sex ratio (females/total) & 0.90 & 0.68 & 0.37 & \\
\hline Gross reproductive rate (GRR) & $100.98 \pm 0.921 \mathrm{a}$ & $87.53 \pm 0.734 c$ & $78.90 \pm 0.657 b$ & $204.338 * *$ \\
\hline
\end{tabular}

${ }^{\mathrm{y}}$ Means within a row followed by the same letter are not significantly different (Tukey HSD, a= 0.05)

${ }^{\mathrm{Z}}$ Numbers between parentheses represent the number of replicates;

**Highly significant at $p=0.000$ 
search has been done by Castilho et al. (2009) indicated that the total fecundity of $P$. posnaniensis fed $T$. puterscentiae was (106.6 eggs/female), which being close to the rhodacarid mite fed E. kuehniella eggs in the present study. Many species of mites of the family Phytoseiidae, it has been proved that the rate of oviposition is completely correlated with the predation rate (Momen, 1996; Momen and El-Borolossy, 1999), because plenty of the material eaten by female mites is adapted into predator eggs.

\section{Effect of E. kuehniella eggs on demographic parameters}

With E. kuehniella eggs, the net reproductive rate (Ro) was significantly higher (99.63 and 86.73) on P. denticus and C. keni, than on L. astronomicus (65.61) (Table 3). The intrinsic rate of natural increase $\left(\mathrm{r}_{\mathrm{m}}\right)$ and consequently, the finite rates of increase $(\lambda)$ were significantly higher on C. keni ( 0.35 and 1.42$)$ than on P. denticus $(0.33$ and 1.39$)$ or L. astronomicus (0.26 and 1.29). The mean generation time ( $\mathrm{T}=16.41$ days) was significantly longer on L. astronomicus, than on P. denticus (13.86 days) or C. keni (12.82 days). The gross reproductive rate (GRR) was significantly higher in P. denticus than on $C$. keni and L. astronomicus. The high value of $(\lambda)$ in $C$. keni could be results from both a short value of (T), which is important and relatively a high value of (Ro). The obtained Ro and $\mathrm{r}_{\mathrm{m}}$ values for both laelapid mites in our study are higher than those reported by Moreira et al. (2015) for $C$. jaboticabalensis fed F. occidentalis and T. puterscentiae as well as $C$. simpex fed C. rodriguezi and M. Javanica (Al-Rehiayani and Fouly, 2005). This difference may be due to the food types and different mites studied.

Our study is the first record of the life history for P. denticus, C. keni and L. astronomicus fed E. kuehniella eggs as a factitious food, and also explained that the tested food being clearly accepted as unnatural food to those predatory mites.

Because, no much data on the real type of food substances that tested predatory mites use in the field, much more work is essential to define what items of food be used.

\section{Literature}

Abou-Awad, B. A., Nasr, A. K., Gomaa, E. A. and Abou-Elela, M. M. (1989): Feeding, development and reproduction of the predatory mite, Hypoaspis vacua on various kinds of food substances (Acari: Laelapidae). Insect Sci. Applic. 10, 503-506.

Ahmed, W. G. O. (1992): Studies on certain predacious mites'species in Sharkia and Giza Governorates. M. Sc. Thesis, Faculty of Agriculture, Zagazig University.

Al-Rehiayani, S. M. and Fouly, A. H. (2005): Cosmolaelaps simplex (Berlese), a polyphagous predatory mites feeding on root-knot nematode Meloidogyne javanica and citrus nematode Tylenchulus semipenetrans. Pak. J. Biol. Sci. 8, 168-174.

Barbosa, M. F. C. and de Moraes, G. J. (2016): Potential of astigmatid mites (Acari:Astigmatina) as prey for rearing edaphic predatory mites of the family Laelapidae and Rhodacaridae (Acari: Mesostigmata). Exp. Appl. Acarol. 69, 289-296.

Beaulieu, F. (2009): Review of the mite genus Gaoelaelaps Evans and Till (Acari: Laelapidae), and description of a new species from North America, G. gillespiei n. sp. Zootaxa 2158, 33-49.

Birch, L. C. (1948): The intrinsic rate of natural increase of an insect population. J. Anim. Ecol. 17, 15-26.

Cabrera, A. R., Cloyd, R. A. and Zaborski, E. R. (2005): Development and reproduction of Stratiolaelaps scimitus (Acari: Laelapidae) with fungus gnat larvae (Diptera: Sciaridae), potworms (Oligochaeta: Enchytraei-

Acta Phytopathologica et Entomologica Hungarica 
dae) or Sancassania aff. sphaerogaster (Acarina: Acaridae) as the sole food source. Exp. Appl. Acarol. 36, 71-81.

Castilho, R. C., de Moraes, G. J., Silva, E. S. and Silva, L. O. (2009): Predation potential and biology of Protogamasellopsis posnaniensis Wisniewski and Hirschmann (Acari: Rhodacaridae). Bio. Cont. 48, 164-167.

De Clercq, P., Merlevede, F. and Tirry, L. (1998): Unnatural prey and artificial diets for rearing Podisus maculiventris (Heteroptera: Pentatomidae). Biol. Cont. 12, 137-142.

Evans, G. O. and Till, W. M. (1979): Mesostigmatic mites of Britain and Ireland (Chelicerata: Acari-Parasitiformes). An introduction to their external morphology and classification. Trans. Zool. Soc. Lond. 35, 139-270.

Evans, G. O. and Purvis, G. (1987): A new ascid mite from St Helena with observation on the Protogamasellus complex (Acari: Mesostigmata). J. Nat. Hist. 25, 855-861.

Fouly, A. H. and Abdel-Baky, N. F. (2015): Influence of prey types on the biological characteristics of Cosmolaelaps qassimensis (Acari: Laelapidae). J. Entomol. 12, 21-29.

Freire, R. A. F. and Moraes, G. J. (2007): Mass production of the predatory mite Stratiolaelaps scimitus (Womersley) (Acari: Laelapidae). Sys. Appl. Acarol. 12, 117-119.

Huang, Y. B. and Chi, H. (2013): Life tables of Bactrocera cucurbitae (Diptera: Tephritidae): with an invalidation of the Jackknife technique. J. Appl. Entomol. 137, 327-339.

Krantz, G. W. (1978): A Manual of Acarology. 2nd ed. Oregon State University Bookstores, Corvallis, 509 p.

Lee, D. C. (1970): Rhodacaridae (Acari: Mesostigmata): classification, external morphology and distribuation of genera. Rec. South Austr. Mus. 16, 1-219.

Mohaghegh, J. and Amir-Maafi, M. (2007): Reproduction of the predatory stinkbug Andrallus spinidens (F.) (Heteroptera: Pentatomidae) on live and frozen prey. Appl. Entomol. Zool. 42, 15-20.

Molla, O., Biondi, A., Alonso-Valiente, M. and Urbaneja, A. (2014): Comparative life history study of two mird bugs preying on Tuta absoluta and Ephestia kuehniella eggs on tomato crops: implications for biological control. BioControl 59, 175-183.

Momen, F. M. (1996): Effect of prey density on reproduction, prey consumption and sex ratio of Amblyseius barkeri (Acari: Phytoseiidae). Acarologia 37, 3-6.

Momen, F. M. and El-Borolossy, M. E. (1999): Fertility and sex ratio of Typhlodromus athiasae and T. negevi under experimental condition: Influence of prey density. Acarologia 40, 227-230.

Momen, F. M. and El-Laithy, A. (2007): Suitability of the flour moth Ephestia kuehniella (Lepidoptera: Pyralidae) for three predatory phytoseiid mites (Acari: Phytoseiidae) in Egypt. Int. J. Trop. Ins. Sci. 27, 102-107.

Moreira, G. F., de Morais, M. R., Busoli, A. C. and de Moraes, M. R. (2015): Life cycle of Cosmolaelaps jaboticabalensis (Acari: Mesostigmata: Laelapidae) on Frankliniella occidentalis (Thysanoptera: Thripidae) and two factitious food sources. Exp. Appl. Acarol. 65, 219-236.

Navarro-Campos, C., Wackers, F. L. and Pekas, A. (2016): Impact of factitious foods and prey the oviposition of the predatory mites Gaeolaelaps aculeifer and Stratiolaelaps scimitus (Acari: Laelapidae). Exp. Appl. Acarol. 70, 69-78.

Nawar, M. A. (2011): Studies on the biological control of some plant infesting pests using predacious mites. Ph. D. thesis, Faculty of Agriculture, Al-Azhar University.

Nguyen, D. T., Vangangansbeke, D. and de Clereq, P. (2014): Artificial and factitious foods support the development and reproduction of the predatory mite Amblyseius swirskii. Exp. Appl. Acarol. 62, 181-194.

Saber, S. A., El-Laithy, A. Y. and Korayem, A. M. (2007): Biology of the predacious mite, Protogamasellus denticus Nasr (Mesostigmata: Ascidae) feeding on different nematode diets. Int. J. Nemat. 17, 17-20.

Sardar, M. A. and Murphy, P. W. (1987): Feeding tests of grassland soil-inhabiting gamasine predators. Acaro$\operatorname{logia} 28,117-121$.

Steiner, M., Goodwin, S. and Wellham, T. (1999): A simplified rearing method for Stratiolaelaps (Hypoaspis) miles (Acari: Laelapidae). IOBC/WPRS 22, 241-242.

Vangansbeke, D., Nguyen, D. T., Audenaert, J., Verhoeven, R., Gobin, B., Tirry, I. and De-Clercq, P. (2014): Performance of the predatory mite Amblydromalus limonicus on factitious foods. BioControl 59, 67-77.

Vantornhout, I., Minnaert, H. L., Tirry, L. and De Clercq, P. (2004): Effect of pollen, natural prey and factitious prey on the development of Iphiseius degenerans. BioControl 49, 627-644. 
Walter, D. E. and Proctor, H. C. (1999): Mites: Ecology, Evolution and Behaviour. CABI Publishing, Wallingford, UK, $352 \mathrm{p}$.

Zhang, Z. Q. (2003): Mites of Greenhouse: Identification, Biology and Control. CABI Publishing, Wallingford, UK, $244 \mathrm{p}$. 